\title{
Korelasi Antara Lari 100 Meter Dengan Prestasi Lompat Jauh Pada Siswa Kelas V SDK Lewodere Tahun Pelajaran 2018/2019
}

\author{
Abrosius Geleuk Dore \\ SDK Leworere Desa Beda Bedalewun Flores Timur NTT \\ ambrosiusgdore@gmail.com
}

\begin{abstract}
Abstrak; Agar dapat meningkatkan prestasi lompat jauh, maka terlebih dahulu kita harus mengetahui faktor-faktor yang dapat memberikan kontribusi bagi peningkatan prestasi lompat jauh tersebut. Kecepatan lari dan kekuatan otot kaki merupakan salah satu faktor penting dalam lompat jauh. Pelompat dapat melakukan awalan dengan baik yaitu berlari secepat-cepatnya yang diakhiri dengan menolak atau menumpu dengan sekuat-kuatnya. Dengan demikian daya dorong ke depan semakin besar, sehingga akan menghasilkan lompatan yang jauh. Apabila seseorang berlari dengan cepat, maka prestasi lompat jauhnya akan baik. Begitupun sebaliknya, apabila seseorang berlari dengan lambat maka prestasi lompat jauhnya kurang baik. Tapi kenyataanya tidak selalu demikian, dalam arti bahwa seseorang yang berlari dengan cepat belum tentu prestasi lompat jauhnya akan selalu baik. Sebaliknya, seseorang yang berlari dengan lambat tidak selalu prestasi lompat jauhnya kurang baik. Tujan penelitan ini adalah "untuk mengetahui ada atau tidakknya korelasi antara kecepatan lari 100 meter dengan prestasi lompat jauh pada sisiwa kelas V SDK Leworere tahun pelajaran 2018/2019. Metode yang digunakan dalam penelitian ini adalah experimen dengan memberikan tes dengan jenis penelitian kualitatif. Populasi dalam penelitian ini adalah siswa SDK Lewodere yang berjumlah 37 orang. Teknik sampel yang digunakan dalam penelitian ini adalah proporsional random sampling. Teknik pengumpulan data dalam penelitian ini 1)Tes perbuatan, 2) Observasi, 3) Dokumentasi. Instrumen penelitian ini dengan tes lari 100 meter dan lompat jauh. Analisis data dengan teknik product moment. Dari hasil uji korelasi product moment diperoleh nilai sebesar 0,765 dengan jumlah sampel $\mathrm{N}=37$ pada taraf signifikansi $5 \%$ ternyata besarnya angka batas penolakan hipotesis nol yang dinyatakan dalam tabel product moment " $r$ " adalah 0,325 Kenyataan ini menunjukkan bahwa " $r$ " yang diperoleh dari hasil analisis data sebesar 0,765 berada diatas angka batas penolakan hipotesis nol yang besarnya 0,325 (nilai $r_{\text {hitung }}$ $\left.=0,765>r_{\text {tabel }}=0,325\right)$ maka dapat disimpulkan bahwa : "Ada Korelasi antara kecepatan lari 100 meter dengan prestasi lompat jauh pada sisiwa kelas V SDK Leworere tahun pelajaran 2018/2019.
\end{abstract}

Kata Kunci: Lari 100 Meter, Lompat Jauh

\section{PENDAHULUAN}

Peranan pemerintah sangat penting dalam usaha meningkatkan kemajuan yang diharapkan, dengan cara menambah dan meningkatkan sarana dan prasarana olahraga yang ada, serta pengiriman atlit untuk latih tanding ke luar negri bahkan mendatangkan pelatih dari luar negri. Selain itu, pihak-pihak yang berkecimpung di bidang olahraga, baik itu sebagai pembina maupun pelatih hendaknya dituntut untuk meningkatkan prestasi anak didik atau anak latihanya terutama dalam cabang olahraga atletik khususnya nomer lompat jauh. Agar dapat meningkatkan prestasi lompat jauh, maka terlebih dahulu kita harus mengetahui unsurunsur atau faktor-faktor yang dapat memberikan kontribusi bagi peningkatan prestasi lompat jauh tersebut. Kecepatan lari dan kekuatan otot kaki merupakan salah satu faktor penting dalam lompat jauh. Pelompat dapat melakukan awalan dengan baik yaitu berlari secepat-cepatnya yang diakhiri dengan menolak atau menumpu dengan sekuatkuatnya. Dengan demikian daya dorong ke depan semakin besar, sehingga akan menghasilkan lompatan yang jauh.

\section{METODE PENELITIAN}

Penelitian ini adalah penelitian eksperimen. Penelitian eksperimen adalah penelitian yang dilakukan untuk mengetahui akibat yang ditimbulkan dari suatu perlakuan yang diberikan secara sengaja oleh peneliti. Desain penelitian yang digunakan adalah pendekatan korelasi, mengetahui korelasi antara kecepatan lari 100 meter dengan dengan prestasi lompat jauh. Yang menjadi populasi dalam penelitian ini adalah siswa kelas $\mathrm{V}$ SDK Leworere yang berjumlah 37. Teknik sampel yang digunakan dalam penelitian ini 
adalah studi populasi. Populasi dalam penelitian ini berjumlah 37 orang siswa kelas V. Untuk memperoleh satu kesimpulan masalah yang diteliti, maka analisis data merupakan satu langkah penting dalam penelitian. Metode yang digunakan dalam penelitian ini adalah eksperimen dengan korelasi, maka untuk teknik analisis data penulis menggunakan rumus product moment.

\section{HASIL PENELITIAN}

Untuk mengolah data-data yang diperoleh pada saat tes lari 100 meter dan tes lompat jauh, maka dilakukan penyusunan tabel kerja antara lain dengan menjadikan nilai kecepatan lari 100 meter sebagai variabel $\mathrm{X}$ dan prestasi lompat jauh sebagai variabel Y. Berdasarkan tabel kerja korelasi product moment di atas diperoleh nilai-nilai sebagai berikut:

$$
\begin{array}{lll}
\Sigma \mathrm{X} & =3345 & \Sigma X^{2}=347573 \\
\Sigma \mathrm{Y} & =4016 & \Sigma Y^{2}=461544 \\
\Sigma \mathrm{XY} & =389118 & \\
N \quad=37 &
\end{array}
$$

Dari hasil analisis data dengan menggunakan rumus korelasi product moment diperoleh nilai koefesien korelasi product moment $\left(r_{\text {hitung }}\right)$ sebesar 0,765 sedangkan besarnya $\left(\mathrm{r}_{\text {tabel }}\right)$ dengan jumlah sampel $\mathrm{N}=37$ pada taraf signifikansi $5 \%$ adalah 0,325 . Dari hasil uji korelasi product moment diperoleh nilai sebesar 0,765 dengan jumlah sampel $\mathrm{N}=37$ pada taraf signifikansi $5 \%$ ternyata besarnya angka batas penolakan hipotesis nol yang dinyatakan dalam tabel product moment " $r$ " adalah 0,325 Kenyataan ini menunjukkan bahwa "r" yang diperoleh dari hasil analisis data sebesar 0,765 berada diatas angka batas penolakan hipotesis nol yang besarnya 0,325 (nilai $\mathrm{r}_{\text {hitung }}=0,765>\mathrm{r}_{\text {tabel }}=0,325$ ) maka dapat disimpulkan bahwa : "Ada Korelasi antara kecepatan lari 100 meter dengan prestasi lompat jauh pada sisiwa kelas V SDK Leworere tahun pelajaran 2018/2019.

\section{PEMBAHASAN}

Mengingat hasil penelitian ini menunjukkan adanya korelasi antara kecepatan lari 100 meter dengan prestasi lompat jauh pada sisiwa kelas V SDK Leworere tahun pelajaran 2018/2019, dengan kata lain bahwa semakin cepata seseorang berlari maka semakin baik juga prestasi yang diraih pada lompat jauh.
Hasil penelitian ini dapat dipertegas dengan kajian teori bahwa di dalam nomor lompat jauh ada beberapa aspek yang mempengaruhi kemampuan seseorang dalam melakukan lompatan untuk mendapatkan prestasi maksimal yaitu kecepatan, penggunaan gaya dan daya ledak. Kecepatan dan percepatan lari sangat diperlukan untuk melakukan tumpuan, tanpa menggunakan kecepatan ang tinggi akan sulit untuk mendapatkan prestasi yang maksimal karena kecepatan yang tinggi sangat dibutuhkan oleh sesorang dalam rangka mendapatkan kekuatan dan daya ledak maksimal unuk melakukan tumpuan dan selanjutnya melakukan lompatan. Dari uraian di atas dapat dikatakan bahwa semakin cepat kemampuan lari sprint seseorang maka prestasi lompat jauhnya akan semakin baik karena dengan kecepatan lari yang tinggi seseorang akan memiliki kekuatan dan daya ledak untuk melakukan tmpuan sehingga akan menghasilkan lompatan yang jauh, demikian juga sebaliknya. Berdasarkan hasil penelitian in iberarti ada kemungkinan seorang atlit lari sprint 100 meter dapat menjadi atlit lompat jauh.

\section{KESIMPULAN}

Dari hasil analisis statistik yang telah diuraikan di atas, maka dapat ditarik kesimpulan yaitu "Korelasi antara kecepatan lari 100 meter dengan prestasi lompat jauh pada sisiwa kelas V SDK Leworere tahun pelajaran 2018/2019. artinya semakin baik kecepatan lari 100 meter siswa maka semakin baik pula prestasi siswa pada nomor lompat jauh demikian juga sebaliknya, semakin tidak baik kecepatan lari 100 meter siswa maka semakin tidak baik pula prestasi siswa pada nomor lompat jauh.

\section{SARAN}

Bertitik tolak dari kesimpulan di atas, maka ada beberapa saran yang penulis sampaikan yaitu :

1. Kepada siswa agar bersungguh-sungguh dalam melakukan latihan, baik latihan kecepatan maupun latihan kekuatan demi tercapainya prestasi lompat jauh yang lebih baik.

2. Kepada pembina dan guru olahraga diharapkan agar memberikan latihan kecepatan lari 100 meter kepada anak 
didik atau anak latihnya karena kecepatan lari dapat memberikan kontribusi terhadap jauhnya hasil lompatan pada nomor lompat jauh.

3. Kepada peneliti lain diharapkan agar dapat meneliti pada hal-hal yang sifatnya mendorong peningkatan prestasi olahraga, khususnya lompat jauh.

\section{DAFTAR PUSTAKA}

Aip, Syarifuddin. 1997 . Panduan Guru Pendidikan Jasmani dan Kesehatan. Jakarta: CV. Grasindo.

Arikunto, Suharsimi. 2002. Prosedur Penelitian. Jakarta: PT. Rineka Cipta.

Carr, A. Gerry. 1997. Atletik untuk Sekolah. Jakarta PT. Raja Grafindo Persada.

Depdikbud. 1984. Petunjuk Praktis Olahraga. Jakarta: Depdikbud.

Hadi, Sutrisno. 1980. Metodologi Research. Yogyakarta: Yaspen. UGM. Yogyakarta.

I.B. Netra. 1974. Statisktik Infrensial. Surabaya: Usaha Nasional.

Khori, Arief. 1987 Kamus Bahasa Bahasa Inggris. Surabaya Mekar

Nurhasan. 2001 Tes dan Pengukuran Dalam Pendidikan Jasmani Kelas Olahraga. Jakarta Direktorat Jendral Olahra

Nurkencana. 1973. Pengukurn dan Penilaian Hasil Belajar. Singaraja Universitas Udayana

Purwadarminto. 1976. Kamus Besar Bahasa Indonesia. Jakarta Balai Pustaka

Riduwan. 2004. metode Riset. Jakarta : Rineka Cipta

Riyadi, Tamsir. 1982. Petunjuk Atletik. Yogyakarta IKIP Yogyakarta

Sugiyono. 2006 Statistik dan Penelitian. Bandung CV. Alfabeta

Surachmad, Winarno. 1972. Metodologi Pengajaran Nasional. Bandung Tarsito

Sutaryono, Yusuf Ahyar. 2003. Pedoman Penulisan Skripsi. IKIP Mataram 